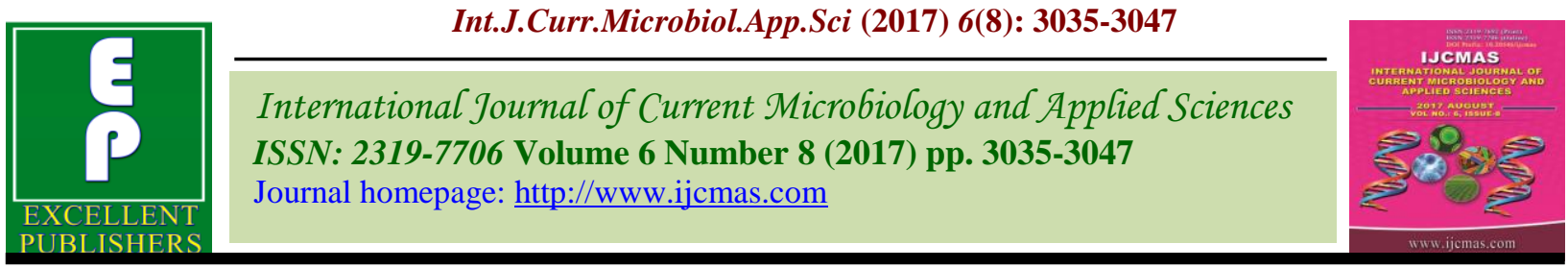

Original Research Article https://doi.org/10.20546/ijcmas.2017.608.363

\title{
Fatty Acid Profile and Physico-Chemical Characteristics of Milk Lipids of Kankrej Cow
}

\author{
Minal Bharwade*, Smitha Balakrishnan, Nisha Chaudhary and A.K. Jain \\ Dairy Chemistry Department, SMC College of Dairy Science, AAU, Anand Gujarat, India \\ *Corresponding author
}

\section{Keywords}

Kankrej cow milk fat, Fatty acids, $\mathrm{RM}$ value, $\mathrm{PV}$, SV, IV, BR.

Article Info

Accepted:

23 June 2017

Available Online:

10 August 2017

\section{A B S T R A C T}

The fatty acid composition of milk fat, which greatly influences the physico-chemical, functional and nutritive properties, is subjected to variation due to species, breed, stage of lactation and feed. Information is sparse on the fatty acid composition and physicochemical charateristics of milk lipids of Kankrej cow, an important dual-purpose breed of the Gujarat. Therefore present work an attempt has been made to characterize the milk lipids of this breed. Level of short chain, medium chain and unsaturated fatty acids were lower while the proportion of long chain saturated fatty acids were higher in the milk fat of Kankrej cow as compared to other indigenous breeds. Kankrej milk fat showed seasonal variations in fatty acid profile. Butyric acid $\left(\mathrm{C}_{4: 0}\right)$ and unsaturated fatty acids $\left(\mathrm{C}_{16: 1}, \mathrm{C}_{18: 1}\right.$, $\mathrm{C}_{18: 2}$ and $\mathrm{C}_{18: 3}$ ) were higher during the period March to June as compared to July to October and November to February. While medium chain fatty $\left(\mathrm{C}_{6: 0}, \mathrm{C}_{8: 0}, \mathrm{C}_{10: 0}, \mathrm{C}_{12: 0}\right.$ and $\left.\mathrm{C}_{14: 0}\right)$ acids and long chain saturated fatty acids $\left(\mathrm{C}_{16: 0}\right.$ and $\left.\mathrm{C}_{18: 0}\right)$ were higher during July to October as compared to the periods March to June and November to February. The conjugated dienoic fatty acids, of which conjugated linoleic acid is a constituent were observed to be lower in milk fat of Kankrej cow than reported for most of the others breeds. The physico-chemical characteristics of Kankrej cow milk fat were also studied. Average Reichert-Meissl (RM) value (28.9), Polenske value (PV,1.6), iodine value (IV, 28.77), butyro-refractometer reading (BR, 42.14) and saponification value (SV, 220.14) for Kankrej cow milk fat was slightly lower in comparison with other indigenous breeds, as governed by the fatty acid profile of milk fat. The average RM value, SV, IV and BR values were higher during March to June while PV was higher during July to October compared to other periods. These seasonal variations in physico-chemical characteristics of Kankrej milk fat were in accordance with changes in fatty acid profile during these periods.

\section{Introduction}

Milk lipids, more commonly referred to as milk fat, form one of the most important class of the constituents of milk. Milk fat plays an important role in the structure, stability, flavour and mouth feel of dairy products and a host of other foods in which milk or milk component are added as functional ingredients. Some of these functional properties have made milk fat a distinctly desirable ingredient in processing and food formulation. Further, as a result of its very well established functions in various product forms, milk fat have been enjoying a substantial market value.

A boarder range of fatty acids (about 400 fatty acids) have been isolated from milk fat (Jensen and Clark, 1988). However, only a 
relative few of these are present in appreciable concentrations $\left(\mathrm{C}_{4: 0}\right.$ to $\left.\mathrm{C}_{18: 0}\right)$ or are of nutritional significance (Mele et al., 2016). These fatty acids are the ones to be considered in making comparison of milk fat from different source. In general, bovine milk fat consists of 65,32 , and $3 \%$ of saturated, monounsaturated and polyunsaturated fatty acids respectively. Milk fat is unique as it contains a large portion of fatty acids of chain length lower than 12 carbon atom; which makes many of its characteristics quite distinctive. These characteristics have therefore been employed for the characterization and differentiation of milk fats.

The fatty acid composition of milk fat, which greatly influences the physico-chemical, functional and nutritive properties, is subjected to variation due to species, breed, stage of lactation and feed. Is subjected to variation due to species, breed, stage of lactation and feed (Rangappa and Achaya, 1974).

Fats exhibit certain physico-chemical characteristics like Reichert-Meissl value which substantially a measure of the short chain fatty acids of milk fat, butyric, caproic and caprylic acid. The extent of these acids contributing to RM value of cow milk fat was reported to be $65.3,30.1$ and 4.6 per cent, respectively (Rai, 2003), polenske value is measure of medium chain fatty acids. Rai (2003) reported that caproic, caprylic, capric and lauric acids contributed to 0.6, 22.1, 76.7 and 0.6 per cent respectively to PV of cow milk fat. saponification value is an indirect measure of average molecular weight of component fatty acids, iodine value (IV), a measure of the extent of unsaturation of milk fat $\left(\mathrm{C}_{18: 1}, \mathrm{C}_{18: 2}\right.$ and $\left.\mathrm{C}_{18: 3}\right)$ and Butyrorefractometer reading measures the index of refraction between air and liquid fat, and varies with nature of milk fat. These characteristics are reflection of the nature and level of the fatty acids. Milk fat is unique as it contains a large portion of fatty acids of chain length lower than 12 carbon atom; which makes many of its characteristics quite distinctive. These characteristics have therefore been employed for the characterization and differentiation of milk fats. Information on the physico-chemical properties of milk lipids of indigenous breed is relatively old and mostly limited to breed such as Tharparkar, Red Sindhi, Gir, Deoni and Haryana. Such information on breed of Kankrej is sparse.

Kankrej is dual purpose cattle breed of Gujarat. They are one of the heaviest dual purpose breed in India. Not much information is available on the physico-chemical characteristics of milk lipids of Kankrej cow. Therefore, in present study, an attempt has been made to characterize the milk lipids from Kankrej breed of cow.

\section{Materials and Methods}

\section{Feeding and management of animals}

Milk sample were collected from herd of pure breed of Kankrej cows maintained at the Livestock research station, Anand Agricultural University, Anand. The herd consisted of 18 cows at different stages of lactation. The cows were fed ad libitium amount of mixed green fodder consisting of maize, sorghum and Napier grass (Coimbatore-2) during summer and monsoon under farm conditions. During summer the proportion of Napier grass fed to the animal was relatively high compared to other seasons. During winter along with sorghum sunflower, oats and cowpea was also fed. The proportion of legume, cowpea was more than 70 per cent of total green fodder during winter. The cows were also given concentrate (Amul dhan) at the rate of $0.5 \mathrm{~kg} /$ litre of milk / day. During all season sorghum hay 
was fed. Each animal was fed 17-18 kg of dry matter/ day.

\section{Collection of milk sample}

The pooled Kankrej cow milk sample was collected at 15 days interval from Livestock Research Station (LRS), AAU, Anand for a period of one year, from March 2016 to February 2017. Total 24 replications for milk of Kankrej cow were carried out. All cows were maintained under identical conditions of feeding and management. The feed given to animals throughout the year consisted of normal concentrate and roughages.

\section{Preparation of ghee sample}

The milk sample were warmed to $40^{\circ} \mathrm{C}$ and then separated into cream using cream separator. Ghee sample was prepared in laboratory by direct cream method (Heat clarification at $120^{\circ} \mathrm{C} /$ no hold). Ghee was then filtered through 6-8 fold muslin cloths followed by Whatman No. 4 filter paper, filled in glass bottles, cool to room temperature and kept in a refrigerator at a temperature of $7 \pm 1^{\circ} \mathrm{C}$ till further analysis.

\section{Gas liquid chromatography system (GLC)}

Auto sampler Agilent GLC - 7890B system equipped with flame ionization detector, $\mathrm{Sr}$. no. US15243005 and column of fused silica capillary with $2.5 \mathrm{~m}$ length, $0.2 \mathrm{~mm}$ internal diameter and $0.25 \mu \mathrm{m}$ film thickness (Superco spm 2560) was used for evaluating fatty acid of fatty acid profile of Kankrej milk fat (Figs. $1-3)$.

\section{Analysis of ghee}

Ghee samples were analysed for physicochemical characteristics such as RM value, $\mathrm{PV}$ value, Saponification value, Iodine value and BR reading by using the method specified in BIS (1981).

\section{Statistical analysis of data}

The data were analysed using Completely Randomized Design (CRD) as per the methods described by Steel and Torrie (1980).

\section{Results and Discussion}

The knowledge of fatty acid composition of milk fat has considerable significance as it determines the physico-chemical properties of fat.

The major fatty acids present in the Kankrej milk fat were the same as those reported for cow milk fat. However considerable variation was observed in their levels. Mean level of short chain fatty acid $\left(\mathrm{C}_{4: 0}\right)$ ranged from 1.5 to 2.4 per cent with an average of 1.96 per cent in the Kankrej milk fat sample. This level appeared to be lower than generally reported by Rama Murthy and Narayanan (1971) for cow milk fat. The average value for short chain fatty acid $\left(\mathrm{C}_{4: 0}\right)$ was highest for the period March to June and lowest during November to February (winter). The cows were fed ad libitium amount of mixed green fodder consisting of maize, sorghum and napier grass (Coimbatore-2) during summer and monsoon under farm conditions. During summer the proportion of napier grass fed to the animal was relatively high compared to other seasons which had contributed to the higher content of butyric acid in summer (March to June).

The level of medium chain fatty acids $\left(\mathrm{C}_{6: 0}\right.$, $\mathrm{C}_{8: 0}, \mathrm{C}_{10: 0}, \mathrm{C}_{12: 0}$ and $\mathrm{C}_{14: 0}$ ) in Kankrej milk fat sample were18.94 per cent, 20.11 and 19.29 per cent for the period March to June, July to October and November to February respectively. The values for medium chain fatty acids were lower when compare to those reported by Smitha et al., (2007). During synthesis of milk fat in mammary gland, the fatty acids of chain length $\mathrm{C}_{4: 0}$ to $\mathrm{C}_{14: 0}$ derived from the blood acetate and $\beta$ - hydroxy 
butyrate while a portion of $\mathrm{C}_{16: 0}$ and virtually all the $\mathrm{C}_{18: 0}$ fatty acids arise from blood lipids (German and Dillard 2006). Therefore any change in the acetate and $\beta$ - hydroxy butyrate or serum lipid to mammary gland would be expected to change the output of different fatty acids in the milk fat. Depression in the acetate production cause the decrease in the synthesis of short chain fatty acids and this was compensated to some extent by an increase uptake of longer chain fatty acids from the blood (Shaw and Laxmanan, 1957).

Low roughage intake or low energy diet cause depression in the production in the acetate (Van Soet, 1963). However, in the present study the feeding regime followed in the farm showed that the animals were given an appropriate quantity of fodder in their feed. The cause for the decrease of short and medium chain fatty acids in the Kankrej milk fat samples observed in study could be attributed to the increase uptake of $\mathrm{C}_{16: 0}$ acid from the blood glycerides which inhibit de novo synthesis in the mammary gland of the short chain fatty acids from acetate.

The level of long chain saturated fatty acids $\left(\mathrm{C}_{16: 0}\right.$ and $\left.\mathrm{C}_{18: 0}\right)$ were 43.08, 47.2 and 46.76 percent respectively in Kankrej milk fat sample for the period March to June, July to October and November to February.

The level of unsaturated chain fatty acids $\left(\mathrm{C}_{16: 1}, \mathrm{C}_{18: 1}, \mathrm{C}_{18: 2}\right.$ and $\left.\mathrm{C}_{18: 3}\right)$ were 26.31 per cent, 25.02 and 25.61 per cent respectively for the period March to June, July to October and November to February.

The mono and poly unsaturated fatty acids in Kankrej milk fat sample for the period March to June, July to October and November to February were 24.62 and 1.69; 23.43 and 1.59; and 24.2 and 1.41 respectively. The lower content of unsaturated fatty acids in Kankrej milk fat might be ascribed to the variation in the extent of hydrogenation of the dietary and $\mathrm{C}_{18: 2}$ and $\mathrm{C}_{18: 3}$ acids by rumen microflora and to the activity of desaturase enzyme which converts $C_{18: 0}$ acid to $C_{18: 1}$ in the mammary gland (Van de Vossenberg and Joblin, 2003).

Conjugated dienoic acids of Kankrej milk fat ranged from 0.515 to 0.597 per cent with an average 0.558 per cent (Table 2 ).

The level of conjugated dienoic acids reported in the present study for Kankrej milk fat was lower than that reported for cow milk fat by Rama Murthy and Narayanan (1972). Lower content of conjugated dienoic acid (CLA) in Kankrej milk fat could be due to the result of extensive partial biohydrogenation of polyunsaturated fatty acid from green feed in the rumen.

It is clear from this study that the fatty acid composition of the Kankrej milk fat is not static. From the foregoing discussion, it may be seen that Kankrej milk fat sample analysed in the present study contained a lower portion of short, medium chain and unsaturated fatty acids and relatively higher proportion of long chain saturated fatty acids.

\section{Physico-chemical characteristics of Kankrej milk fat}

Five analytical characteristics may be considered of basic importance. Of these, three determinations, the Reichert-Meissl (RM) value, the Polenske value (PV) and the Iodine value (IV) measure certain specific constituents of milk fat. Two other characteristics, the Saponification value (SV) and Butyro - refractometer (BR) reading or refractive index $(\mathrm{RI})$ give an indication of the overall average nature of the constituent acids present. 


\section{Int.J.Curr.Microbiol.App.Sci (2017) 6(8): 3035-3047}

Fig.1 Gas liquid chromatogram of fatty acid methyl esters of pooled Kankrej milk fat for the period March to June (summer)

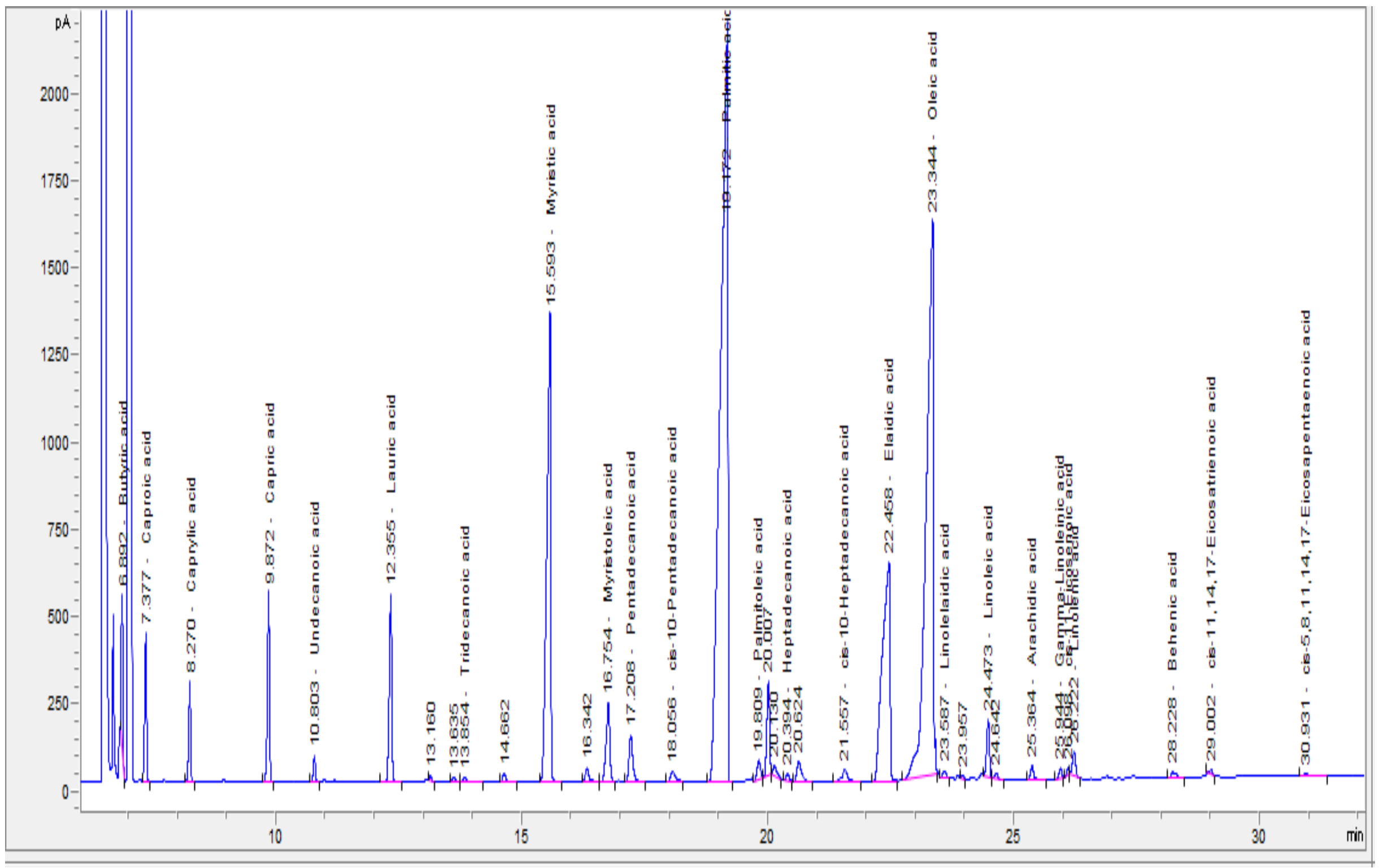




\section{Int.J.Curr.Microbiol.App.Sci (2017) 6(8): 3035-3047}

Fig.2 Gas liquid chromatogram of fatty acid methyl esters of pooled Kankrej milk fat for the period July to October (rainy season)

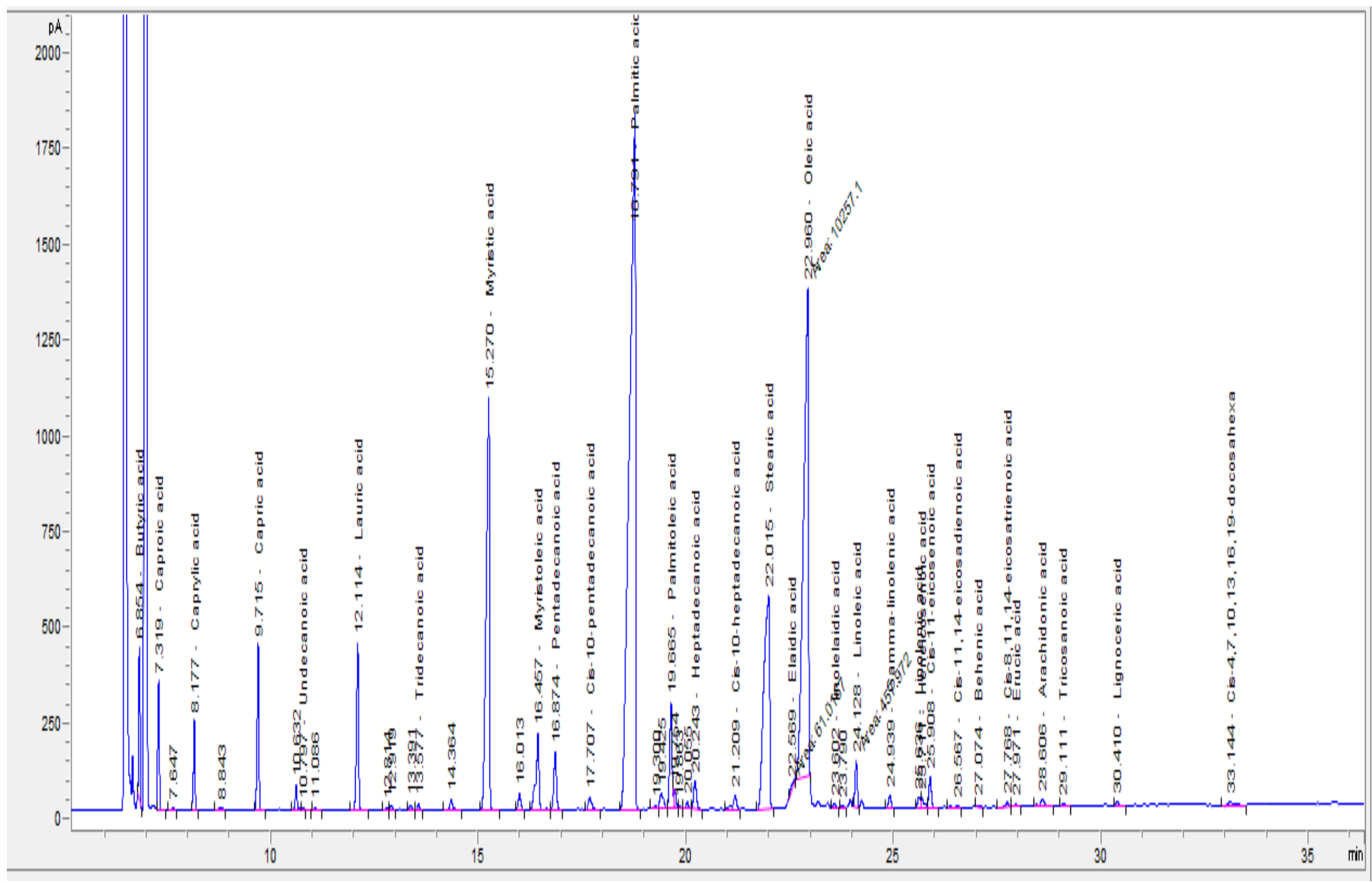

3040 


\section{Int.J.Curr.Microbiol.App.Sci (2017) 6(8): 3035-3047}

Fig.3 Gas liquid chromatogram of fatty acid methyl esters of pooled Kankrej milk fat for the period November to February (winter)

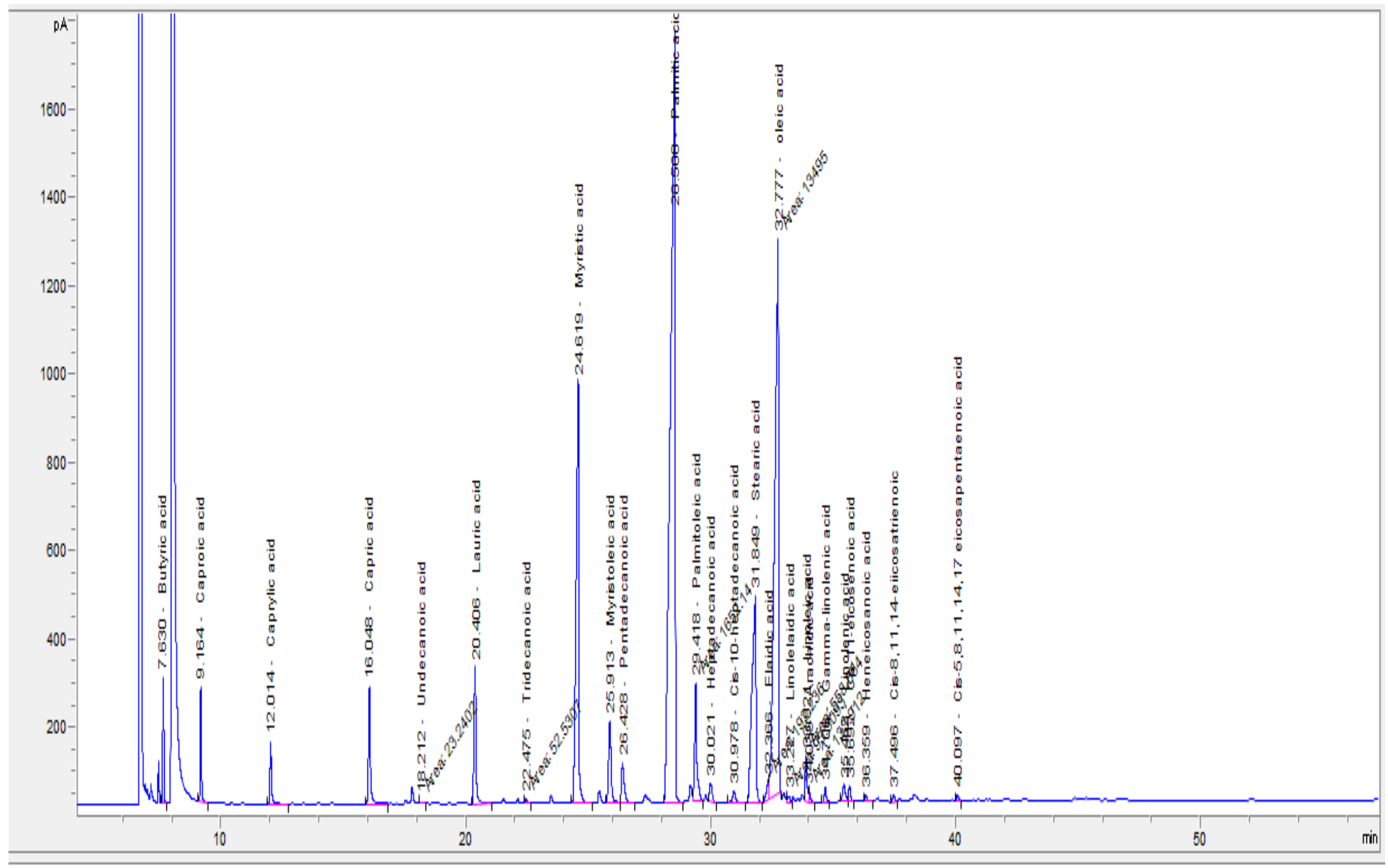

3041 
Table.1 Fatty acid composition of Kankrej milk fat

\begin{tabular}{|c|c|c|c|c|c|c|c|c|c|c|c|c|c|}
\hline \multirow[t]{2}{*}{ Period $* *$} & \multirow{2}{*}{$\begin{array}{c}\text { Sample } \\
\text { No. }\end{array}$} & \multicolumn{12}{|c|}{ Fatty acid $(\%)^{*}$} \\
\hline & & $4: 0$ & $6: 0$ & 8:0 & 10:0 & $12: 0$ & $14: 0$ & $16: 0$ & $16: 1$ & 18:0 & $18: 1$ & $18: 2$ & $18: 3$ \\
\hline $\begin{array}{c}\text { March } \\
\text { to } \\
\text { June } \\
\text { (Summer season) }\end{array}$ & 1 & 2.46 & 1.73 & 1.12 & 2.39 & 2.83 & 10.87 & 33.18 & 0.44 & 9.90 & 24.18 & 1.08 & 0.61 \\
\hline $\begin{array}{c}\text { July } \\
\text { to } \\
\text { October } \\
\text { (Rainy season) }\end{array}$ & 2 & 1.94 & 1.81 & 1.21 & 2.53 & 3.01 & 11.55 & 36.35 & 2.69 & 10.85 & 20.74 & 0.91 & 0.68 \\
\hline $\begin{array}{c}\text { November } \\
\text { to } \\
\text { February } \\
\text { (Winter season) }\end{array}$ & 3 & 1.50 & 1.43 & 1.01 & 2.26 & 2.91 & 11.68 & 37.97 & 2.17 & 8.79 & 22.03 & 0.91 & 0.50 \\
\hline Mean & & 1.96 & 1.65 & 1.11 & 2.39 & 2.91 & 11.36 & 35.83 & 1.76 & 9.84 & 22.31 & 0.96 & 0.59 \\
\hline SD & & 0.48 & 0.20 & 0.10 & 0.13 & 0.09 & 0.43 & 2.43 & 1.17 & 1.03 & 1.73 & 0.09 & 0.09 \\
\hline
\end{tabular}


Table. 2 Conjugated dienoic fatty acids of Kankrej milk fat

\begin{tabular}{|l|c|}
\hline Period & Dienoic fatty acid (\%) \\
\hline March 2016 & 0.588 \\
\hline April 2016 & 0.591 \\
\hline May 2016 & 0.593 \\
\hline June 2016 & 0.597 \\
\hline July 2016 & 0.545 \\
\hline August 2016 & 0.545 \\
\hline September 2016 & 0.540 \\
\hline October 2016 & 0.550 \\
\hline November 2016 & 0.515 \\
\hline December 2016 & 0.535 \\
\hline January 2017 & 0.555 \\
\hline February 2017 & 0.545 \\
\hline Average & 0.558 \\
\hline SEm \pm & 0.007 \\
\hline CD $(0.05)$ & 0.021 \\
\hline CV \% & 1.732 \\
\hline
\end{tabular}

Table.3 Physico-chemical characteristics of Kankrej milk fat

\begin{tabular}{|l|c|c|c|c|c|}
\hline Period & $\begin{array}{c}\text { Reichert- } \\
\text { Meissl } \\
\text { value }\end{array}$ & $\begin{array}{c}\text { Polenske } \\
\text { value }\end{array}$ & $\begin{array}{c}\text { Saponification } \\
\text { value }\end{array}$ & Iodine value & $\begin{array}{c}\text { Butyro- } \\
\text { refractometer } \\
\text { reading (40 C) }\end{array}$ \\
\hline March 2016 & 29.50 & 1.60 & 223.40 & 29.55 & 42.25 \\
\hline April 2016 & 29.60 & 1.60 & 223.80 & 29.50 & 42.50 \\
\hline May 2016 & 29.60 & 1.60 & 223.90 & 29.45 & 42.75 \\
\hline June 2016 & 29.50 & 1.60 & 224.15 & 29.55 & 42.75 \\
\hline July 2016 & 28.85 & 1.70 & 214.75 & 28.15 & 41.70 \\
\hline August 2016 & 28.65 & 1.70 & 216.80 & 28.05 & 41.28 \\
\hline $\begin{array}{l}\text { September } \\
\text { 2016 }\end{array}$ & 28.80 & 1.70 & 217.15 & 28.10 & 42.05 \\
\hline October 2016 & 28.70 & 1.70 & 217.05 & 28.25 & 41.75 \\
\hline $\begin{array}{l}\text { November } \\
\text { 2016 }\end{array}$ & 28.30 & 1.50 & 221.75 & 28.55 & 42.50 \\
\hline $\begin{array}{l}\text { December } \\
\text { 2016 }\end{array}$ & 28.50 & 1.50 & 218.50 & 28.65 & 42.00 \\
\hline January 2017 & 28.35 & 1.50 & 220.90 & 28.80 & 42.50 \\
\hline February 2017 & 28.45 & 1.50 & 219.45 & 28.65 & 41.75 \\
\hline Average & 28.9 & 1.6 & 220.14 & 28.77 & 42.14 \\
\hline SEm \pm & 0.07 & 0.03 & 0.69 & 0.04 & 0.22 \\
\hline CD (0.05) & 0.24 & 0.09 & 2.13 & 0.13 & 0.68 \\
\hline CV \% & 0.38 & 2.78 & 0.44 & 0.21 & 0.74 \\
\hline
\end{tabular}


Table.4 Seasonal variations in the physico-chemical characteristics of kankrej milk fat

\begin{tabular}{|c|c|c|c|c|c|}
\hline Period & $\begin{array}{l}\text { Reichert- } \\
\text { Meissl } \\
\text { value* }\end{array}$ & $\begin{array}{c}\text { Polenske } \\
\text { value* }\end{array}$ & $\begin{array}{c}\text { Saponification } \\
\text { value* }^{*}\end{array}$ & $\begin{array}{l}\text { Iodine } \\
\text { value* }\end{array}$ & $\begin{array}{c}\text { Butyro- } \\
\text { refractometer } \\
\text { reading }\left(40^{\circ} \mathrm{C}\right)^{*}\end{array}$ \\
\hline $\begin{array}{c}\text { March } 2016 \\
\text { to } \\
\text { June } 2016 \\
\text { (Summer season) }\end{array}$ & $29.56^{\mathrm{c}}$ & $1.61^{\mathrm{a}}$ & $223.18^{c}$ & $29.51^{\mathrm{c}}$ & $42.50^{\mathrm{c}}$ \\
\hline $\begin{array}{c}\text { July } 2016 \\
\text { to } \\
\text { October } 2016 \\
\text { (Rainy season) } \\
\end{array}$ & $28.75^{\mathrm{b}}$ & $1.73^{\mathrm{a}}$ & $216.46^{\mathrm{a}}$ & $28.13^{\mathrm{a}}$ & $41.60^{\mathrm{a}}$ \\
\hline $\begin{array}{l}\text { November } 2016 \\
\text { to } \\
\text { February } 2017 \\
\text { (Winter season) }\end{array}$ & $28.40^{\mathrm{a}}$ & $1.56^{\mathrm{b}}$ & $220.15^{\mathrm{b}}$ & $28.66^{\mathrm{b}}$ & $42.10^{\mathrm{b}}$ \\
\hline SEm \pm & 0.03 & 0.01 & 0.44 & 0.03 & 0.13 \\
\hline $\mathrm{CD}(0.05)$ & 0.11 & 0.05 & 1.30 & 0.09 & 0.39 \\
\hline $\mathrm{CV} \%$ & 0.38 & 2.86 & 0.56 & 0.30 & 0.89 \\
\hline
\end{tabular}

Milk fat is unique in that it contains a large proportion of fatty acids of chain length lower than 12 carbon atoms, and in consequence many of its characteristics are quit distinctive.

Therefore some of its characteristics like RM value and $\mathrm{BR}$ reading find place in the FSSA (2011) standards. In addition to these two characteristics, AG Mark has specification for PV also in its standards for ghee.

\section{Reichert-Meissl (RM) value}

The RM value of Kankrej milk fat in present study ranged from 28.30 to 29.60 with an average of 28.90 (Table 3). Javed et al., (1986) observed that RM value of Deoni milk fat was in the range of 26 to 29.9.

This appeared to be slightly lower than that reported for milk fat of certain breeds of cattle, the probable reason could be low content of butyric and caproic acid in Kankrej milk fat. Even then the RM value of Kankrej milk fat (as reported in Table 3) meet the requirement prescribed by FSSA for Gujarat state (minimum 24).

It can be seen from table 4 that the average RM value for Kankrej milk fat was highest during the period from March to June (29.56) i.e. summer season and the lowest during the from period November to February i.e. winter season (28.40). And for the period from July to October it was 28.75 (rainy season).

The highest RM value observed during March to June compared to other two periods can be ascribed to the higher level of butyric acid (2.46 per cent) present in Kankrej milk fat for the pooled fat samples of these months i.e. summer season (Table 1).

\section{Polenske Value (PV)}

The PV for Kankrej milk fat, as shown in table 3, ranged from 1.5 to 1.7 with an average of 1.6 . 
The PV value of Kankrej milk fat was within the limit (1-2) prescribed by AG Mark standards (1938).

It can be seen from table 4 that the average PV for Kankrej milk fat was highest during the period from July to October (1.73) i.e. rainy season and the lowest during November to February (1.56) i.e. winter season. The average PV for the period from March to June was 1.61 (summer season).

The higher level of caproic, caprylic capric and lauric acids $(1.81,1.21,2.53$ and 3.01 per cent respectively) present in Kankrej milk fat in the months from July to October (Table 1) could be attributed to the higher average PV value observed during this period. This could possibly be due to the effect of differences in the animal feed in different seasons leading to generation of different levels of precursors for the synthesis of short chain fatty acids in the mammary gland. The fluctuations in PV with the month of the year have also been observed earlier by some other workers (Aghav et al., 2014; Upadhyay, 2014).

\section{Saponification Value (SV)}

The SV of Kankrej milk fat ranged from 216.80 to 224.15 with an average value of 220.14 (Table 3). It was observed in the present study that total long chain fatty acids $\left(\mathrm{C}_{16: 0}\right.$ and $\left.\mathrm{C}_{18: 0}\right)$ ranged between 43.08 to 47.20 per cent (Table 1), and in general were higher for Kankrej milk especially for palmitic acid. When compared to values reported by other workers.

Lakshminarayanan and Rama Murthy (1985) and smitha et al., (2007) reported 43.6 and 40.75 per cent of long chain fatty acids in cow milk and deoni milk fat respectively. This could be reason for the lower SV of Kankrej milk fat sample reported in the present study compared to other literature values.
From table 4 It can be seen that the average SV for Kankrej milk fat was highest during March to June (223.81) i.e. summer season and lowest during July to October (216.46) i.e. rainy season. And for the period from November to February (winter season), the average SV for Kankrej milk fat was 220.15.

The higher level of medium $\left(\mathrm{C}_{6: 0}, \mathrm{C}_{8: 0}, \mathrm{C}_{10: 0}\right.$, $\mathrm{C}_{12: 0}$ and $\mathrm{C}_{14: 0}$ ) and long chain fatty acids $\left(\mathrm{C}_{16: 0,0}, \mathrm{C}_{18: 0}, \mathrm{C}_{18: 1}\right)$ were present in the Kankrej milk fat samples during the period July to October (67.3 per cent), followed by fat samples for the period November to February (66.05 per cent) and lowest was recorded for the period March to June (62.02 per cent) as shown in table 1 .

As the SV is inversely proportional to the mean molecular weight of fatty acids, the fatty acid profile for medium and long chain fatty acid of respective period correlates well with their average $S V$ value.

\section{Iodine Value (IV)}

Iodine value (IV), a measure of the extent of unsaturation of milk fat $\left(\mathrm{C}_{18: 1}, \mathrm{C}_{18: 2}\right.$ and $\left.\mathrm{C}_{18: 3}\right)$, ranged from 28.05 to 29.55 with an average 28.77 for Kankrej milk fat (Table 3). The unsaturated fatty acid $\left(\mathrm{C}_{16: 1}, \mathrm{C}_{18: 1}, \mathrm{C}_{18: 2}\right.$ and $\mathrm{C}_{18: 3}$ ) level was observed to be lower for Kankrej milk fat ranging from 25.02 to 26.31 per cent (Table 1) compared to values 30.2 and 38.38 per cent by Lakshminarayanan and Rama Murthy (1985) and Smitha et al., (2007). This is could be the reason for lower IV for Kankrej milk fat samples observed in the present study.

It can be seen from table 4 that the average IV for Kankrej milk fat was highest during period March to June (29.51, summer season) followed by November to February (28.66, winter season) and lowest for period July to October (28.13 rainy season). 
Since the iodine value gives the degree of unsaturation, it can be correlated with the mono unsaturated $\left(\mathrm{C}_{16: 1}, \quad \mathrm{C}_{18: 1}\right)$ and polyunsaturated fatty acids $\left(\mathrm{C}_{18: 2}, \mathrm{C}_{18: 3}\right)$. The total unsaturated fatty acids were highest during the period March to June (26.31 per cent) followed by November to February (25.61 per cent) and lowest was recorded during July to October (25.02 per cent) as shown in table 1 . It can be directly correlated to the higher mean IV value observed during periods.

\section{Butyro-Refractometer (BR) Reading}

BR Reading measures the index of refraction between air and liquid fat, and varies with nature of milk fat. BR reading ranged from 41.28 to 42.75 with an average 42.14 for Kankrej milk fat (Table 3). The BR reading of Kankrej milk fat in the present study was within the range reported by other researchers and also was well within the limit given by FSSA (2011) is in the range of 40 to 43.5 for Gujarat state.

It can be seen from table 4 that the average BR reading observed was highest for the period from March to June (42.5) and lowest during July to October (41.6). An average BR of 42.1 was observed during November to February for Kankrej milk fat.

In homologous series of saturated fatty acids from butyric to stearic, the BR reading rises steeply among lower numbers and flattens out at higher chain lengths. An increase of the BR in milk fat is caused by decrease in the content of lower fatty acids, or by an increase either in higher saturated or unsaturated fatty acids, particularly latter (Rangappa and Achaya, 1974).

The total unsaturated fatty acids (mono unsaturated $\left(\mathrm{C}_{16: 1}, \mathrm{C}_{18: 1}\right)$ and polyunsaturated fatty acids $\left(\mathrm{C}_{18: 2}, \mathrm{C}_{18: 3}\right)$ of pooled milk fat samples were highest for the period March to June (26.31 per cent) followed November to February (25.61 per cent) and lowest was recorded for the period July to October (25.02 per cent). BR reading can be directly correlated to the presence of higher mono and poly unsaturated fatty acids in fat of milk samples collected during the period March to June (29.51) i.e. summer season and lowest to those during the period July to October (28.13) i.e. rainy season (Table 1). Variations observed in BR reading in different months for Kankrej milk fat is due to the changes in the unsaturated fatty acids recorded during these periods. The fluctuations observed in BR reading in the present study with the month of the year have also been observed earlier by some other workers as a consequence of seasonal variation (Aghav et al., 2014; Upadhyay, 2014).

\section{References}

Aghav, A. D., Gandhi, K., Upadhyay, N., Kumar, A. and Lal, D. 2014. A study on the physico-chemical changes occurring in the milk fat during preparation of Paneer. Indian J. Dairy Sci., 67: 398404.

Agmark, 1938. Ghee Grading and Marketing Rules (AG MARK). Principle rules published under the notification of the Govt. of India, Imperial council of Agricultural Research No.F- 51-(45)38/ G. I. Dated 29-7-38 in the Gazette of India, Part- I dated 30-7-38.

FSSA 2011. Food Safety and Standards (Food Product Standards and Food Additives) Regulations, Food Safety and Standard Authority of India. Ministry of Health and Family Welfare, Government of India, New Delhi.

German, J. B., and Dillard, C. J. 2006. Composition, structure and absorption of milk lipids: a source of energy, fatsoluble nutrients and bioactive 
molecules. Critical reviews in food sci. and nutr, 46: 57-92.

Javeed, S. I., Rathi, S. D. and Ingle, V. M. 1986. Physico-chemicals constants of ghee prepared from Deoni cow, crossbreed cow and Surti buffalo milk. Indian J. Dairy Sci., 4: 491-492.

Jensen, R. C. and Clark, R. W. 1988. Lipid composition and properties: Fundamentals of Dairy chemistry. Van Nostrand Reinhold, New York, pp.171213.

Lakshminarayanan, M. and Rama Murthy, M. K. 1985. Cow and buffalo milk fat fractions: Part I- Yield, Fatty acid composition and physico-chemical characteristics of the fractions. Indian $J$. Dairy Sci., 38: 256-264.

Mele, M., Macciotta, N. P. P., Cecchinato, A., Conte, G., Schiavon, S. and Bittante, G. 2016. Multivariate factor analysis of detailed milk fatty acid profile: Effects of dairy system, feeding, herd, parity, and stage of lactation. J. of Dairy Sci., 99: $1-14$.

Rai, T., 2003. Analytical techniques in dairy chemistry with special reference to chemical quality of milk and milk products. 26-34.

Rama Murthy, M. K. and Narayanan, K. M. 1971. Buffalo and cow milk fat by gasliquid chromatography. Milchwissenschaft, 26: 693- 697.

Rama Murthy, M. K., \& Narayanan, K. M. 1972. Polyunsaturated fatty acids of cow and buffalo milk fat. Milchwissenschsft, 27, 695-698.

Rangappa K. S., and Achaya, K. T. 1974. Indian Dairy products. Asian publishing House, Bombay, pp. 213-327.

Shaw, J. C., and Laxmanan, S. 1957. Atomic energy and Agriculture. AAAS Symposium. Vol. 49, Wanshinton D.C.

Smitha. B., Arumughan, C. and Surendra Nath, B. 2007. Fatty acid composition of milk fat of Deoni breed of cattle. Indian J. dairy sci., 60: 81-85.

Steel, R. G. D., \& Torrie, J. H. 1980. Principles and procedure of statistics- a biometrical approach. Japan: Mcgraw Hill Kogakusha Ltd., Japan, pp: 137143.

Upadhyay, N., 2014. Detection of vegetable oil and animal body fat adulteration in ghee using solvent fractionation technique. Ph.D. Thesis submitted to the National Dairy Research Institute, Karnal, India.

Van De Vossenberg, J. L. and Joblin, K. N. 2003. Biohydrogenation of $\mathrm{C}_{18}$ unsaturated fatty acids to stearic acid by a strain of Butyrivibrio hungatei from the bovine rumen. Lett. In Appl. Microbiol., 37:424-428.

Van Soet, 1963. Ruminant fat metabolism with particular reference to factors affecting low milk fat and feed efficiency: A review. J. Dairy Sci., 46: 204-216.

\section{How to cite this article:}

Minal Bharwade, Smitha Balakrishnan, Nisha Chaudhary and Jain, A.K. 2017. Fatty Acid Profile and Physico-Chemical Characteristics of Milk Lipids of Kankrej Cow. Int.J.Curr.Microbiol.App.Sci. 6(8): 3035-3047. doi: https://doi.org/10.20546/ijcmas.2017.608.363 